\title{
Weeds and Their Responses to Management Efforts in A Changing Climate
}

\author{
Md. Parvez Anwar 1,2,* A. K. M. Mominul Islam 1,2 ${ }^{\mathbb{D}}$, Sabina Yeasmin 1,2 ${ }^{\mathbb{D}}$, Md. Harun Rashid ${ }^{2}$, \\ Abdul Shukor Juraimi ${ }^{3}$, Sharif Ahmed ${ }^{4}$ iD and Anil Shrestha ${ }^{5}$ (D) \\ 1 Agro Innovation Laboratory, Department of Agronomy, Bangladesh Agricultural University, \\ Mymensingh 2202, Bangladesh; akmmominulislam@bau.edu.bd (A.K.M.M.I); \\ sabinayeasmin@bau.edu.bd (S.Y) \\ 2 Department of Agronomy, Bangladesh Agricultural University, Mymensingh 2202, Bangladesh; \\ mhrashid@bau.edu.bd \\ 3 Department of Crop Science, Faculty of Agriculture, University Putra Malaysia, Serdang 43400, Malaysia; \\ ashukur@upm.edu.my \\ 4 International Rice Research Institute, Bangladesh Office, Dhaka 1213, Bangladesh; s.ahmed@irri.org \\ 5 Department of Viticulture and Enology, California State University, Fresno, CA 93740, USA; \\ ashrestha@mail.fresnostate.edu \\ * Correspondence: parvezanwar@bau.edu.bd; Tel.: +880-1912-114281
}

Citation: Anwar, M.P.;

Islam, A.K.M.M.; Yeasmin, S.

Rashid, M.H.; Juraimi, A.S.;

Ahmed, S.; Shrestha, A. Weeds and

Their Responses to Management

Efforts in A Changing Climate.

Agronomy 2021, 11, 1921. https://

doi.org/10.3390/agronomy11101921

Academic Editors: James V. Anderson and David P. Horvath

Received: 6 September 2021

Accepted: 23 September 2021

Published: 25 September 2021

Publisher's Note: MDPI stays neutral with regard to jurisdictional claims in published maps and institutional affiliations.

Copyright: (c) 2021 by the authors. Licensee MDPI, Basel, Switzerland. This article is an open access article distributed under the terms and conditions of the Creative Commons Attribution (CC BY) license (https:/ / creativecommons.org/licenses/by/ $4.0 /)$.
Abstract: Crop production is a constant battle with weeds, in which weeds, generally, are victorious. Therefore, rather than channeling our efforts into the development of a "silver bullet" to control weeds, the focus should be on sustainable weed management in both natural- and agro-ecosystems. However, sustainable weed management can be a challenge in the context of global climate change. Over the past few decades, global climate change, mostly indicated by phenomena such as increased atmospheric temperature and elevated $\mathrm{CO}_{2}$ levels, is evident due to human activities and natural events. These phenomena also affect regional/local climate, resulting in significant influences on the agricultural systems of a particular region. Rising $\mathrm{CO}_{2}$ levels may give comparative advantages to $C_{3}$ plants through increased photosynthesis, biomass production and yield, compared to $C_{4}$ plants. Plants with $\mathrm{C}_{4}$ photosynthetic pathways, on the other hand, are likely to benefit more from rising global temperatures than $C_{3}$ plants. Thus, the differential responses of $C_{3}$ and $C_{4}$ plants to climate change may alter crop-weed interactions and competition outcomes, most likely at the expense of the crop. Climate change will likely cause shifts in weed community compositions, their population dynamics, life cycle, phenology, and infestation pressure. Some weed species may go extinct, while some others may become more aggressive invaders. Weeds are, generally, colonizers and have some unique biological traits and ecological amplitudes that enable them to successfully dominate crops in a habitat with changed environmental conditions. Moreover, climate shifts, especially erratic rainfall and drought, may affect herbicide selectivity and efficacy or the success of bio-control agents resulting in an establishment of a mixed and complex population of $\mathrm{C}_{3}$ and $\mathrm{C}_{4}$ weed species adding to the complexity of weed management. Although elevated $\mathrm{CO}_{2}$ levels will stimulate the productivity of major $\mathrm{C}_{3}$ crops, most troublesome agricultural weeds will likely be more responsive to a rise in $\mathrm{CO}_{2}$ than crops, and thus may dominate the agro-ecosystem. It is predicted that, as temperature rises, the majority of the $\mathrm{C}_{4}$ weeds will flourish and will pose serious crop yield losses. Understanding and assessment of the impact of simultaneous changes in multiple climate factors and their complex interactions on crops and weeds are therefore necessary to formulate an adaptive weed management approach and build resilience. Moreover, strategic policies and strong actions need to be taken to reduce the root causes of $\mathrm{CO}_{2}$ and other greenhouse gas emissions to minimize the impact of climate change on weed biology and management.

Keywords: global warming; weed shift; weed demography; crop-weed competition; weed management; herbicide resistance 


\section{Introduction}

As the global population is estimated to reach 10 billion by 2050 [1], ensuring sufficient quality food for the burgeoning human population will be a fundamental challenge [2] for food producers, researchers, and policy makers worldwide. The challenges include shrinking natural resources (water, land), ecosystem degradation, pest management, and anthropogenic climate change, among others. It is indisputable that sustainable food production is foremost to ensure food security, which includes availability, accessibility, and system stability [3]. Since climate plays a crucial role in the growth, development, and existence of any living organism, crops are highly vulnerable to any changes in climatic parameters [4]. Moreover, climate is the key determinant of crop distribution at regional and global levels [5], and hence agriculture may be jeopardized by climate change [6]. Climate can potentially interfere with crop productivity and in turn, human welfare to a great extent.

A major threat to crop production that growers continually battle with are undesirable plant species, deemed as weeds. On a global scale, Oerke [7] estimated that weeds caused approximately $34 \%$ yield loss in crops. Weeds are opportunist plant species that are well adapted to colonize and, in many cases, dominate an ecosystem by forming an extensive population. Other than wide ecological amplitudes, a set of unique biological characteristics like competitiveness, aggressiveness, adaptability, and high fecundity enable weeds to survive in a wide range of adverse environmental conditions in crop fields or any other disturbed habitats [8]. As per Darwinian concept of "struggle for existence", weeds are the most successful species evolved on Earth [9]. Unlike other crop pests, weeds share a similar trophic level and compete with crops for limited resources like water and nutrients causing huge crop yield reductions [4]. Apart from yield loss in crops weeds are also known to have negative impact on rangelands [10], forests [11], and ecosystem dynamics including species diversity [12]. Therefore, effective weed control and management are crucial to sustain crop productivity.

Climate change, mostly indicated by global warming, is now a well-accepted phenomenon contributed by both natural and human activities. As per Inter-governmental Panel of Climate Change (IPCC), "climate change refers to any change in the state of climate identified by fluctuations in the mean and/or the variability of its properties due to natural event or human activities, and that persists for a longer period like decades or more". On the contrary, the United Nations Frame Work Convention on Climate Change (UNFCCC) refers to climate change as "the change of climate that is attributed directly or indirectly to human activity that alters the composition of the global atmosphere and that is in addition to natural climate variability observed for comparable time periods" [13]. Increased temperature and atmospheric $\mathrm{CO}_{2}$ level are considered two major drivers of climate change. The terms "greenhouse gas" and "greenhouse effect" are always used in conjunction with the phenomenon of climate change. The Earth's surface is warmed by short-wave radiation from the sun, and after intercepting a small part of this radiation, the Earth, in-turn, radiates energy (in longer wavelength) back to space, known as terrestrial radiation [14]. Some atmospheric gases mostly water vapor, $\mathrm{CO}_{2}$ and other trace gases $\left(\mathrm{CH}_{4}, \mathrm{~N}_{2} \mathrm{O}, \mathrm{CFCs}\right)$ absorb some terrestrial radiation that warms up the Earth's surface. These gases are, therefore, known as greenhouse gases and the rise in temperature effect is called the "natural greenhouse effect" of the atmosphere, because it is somewhat similar to the effect produced by the gases inside the glass panels of a real greenhouse $[8,15]$. Over the last two centuries, rapid industrialization along with increasing global demand for power intensified fossil fuel (coal, oil, gas) combustion, massive deforestation, bush burning and clearing land for agricultural purposes, and stubble burning has resulting in increased greenhouse gas emission and atmospheric $\mathrm{CO}_{2}, \mathrm{CH}_{4}$, and $\mathrm{N}_{2} \mathrm{O}$ concentrations [8,15].

Atmospheric $\mathrm{CO}_{2}$ concentration has been continuously rising from about $280 \mathrm{ppm}$ (pre-industrial period) till date and may exceed $800 \mathrm{ppm}$ by the end of the 21st century at the current pace of emission due to fossil fuel burning and deforestation [16]. Global climate model projects that mean global surface temperature will increase by $1.5-4.5^{\circ} \mathrm{C}$ in the 21st century resulting from doubling of $\mathrm{CO}_{2}$ concentrations and enhanced greenhouse 
effect [17]. In another report, the IPCC [13] claimed that, since the nineteenth century an average increase of $0.76^{\circ} \mathrm{C}$ in the Earth's mean annual surface temperature has already occurred. It is so alarming that about $50 \%$ of the anthropogenic $\mathrm{CO}_{2}$ emissions between 1750 and 2011 have occurred in the last 40 years [18]; of which, around $40 \%$ of the $\mathrm{CO}_{2}$ emissions remain in the atmosphere and the rest on land (soil and plant) and in oceans. The unprecedented atmospheric burden of two important greenhouse gases $\left(\mathrm{CO}_{2}\right.$ and $\left.\mathrm{CH}_{4}\right)$ has emerged as the greatest ecological challenge of the current century [6]. In addition to $\mathrm{CO}_{2}$ enrichment and global warming, human activities also cause interference in ozone $\left(\mathrm{O}_{3}\right)$ concentrations (decrease in stratospheric and increase in tropospheric layers) along with nitrogenous compound decomposition in ecosystems from the atmosphere, resulting in significant negative impact on natural ecosystems and in turn agricultural productivity [8]. As predicted by global climate models, the mean increases in global temperature by the end of the 21 st century will be $1.0-3.7^{\circ} \mathrm{C}$ [19]. What is more alarming is that 9 out of the 10 warmest years since 1880 have occurred during the last decade (2000-2010) [20].

Climate change is a looming crisis in agriculture. Both crop and weed species respond to climate change, but the impacts are still unclear in many cases. Especially, the consequences of interactions between two or more factors (like $\mathrm{CO}_{2}$, temperature, water) for either crop or weed species are very poorly understood. Furthermore, the complexity derived from the multiple interacting factors may produce unexpected dramatic indirect effects on the agroecosystem [21]. In general, the stimulatory or inhibitory behavior of climate change on crops might also hold true for weeds [15], but most probably, in many cases, weeds are likely to outcompete crops because of their higher plasticity, superior adaptability, and wider ecological amplitudes compared to crops. There are reasons to believe that increasing temperatures, $\mathrm{CO}_{2}$ concentrations, and associated problems like erratic rainfall, frequent cyclones, and storms will certainly aggravate the problem of weeds and make them difficult to manage. Until now it has been a big question whether or not $\mathrm{CO}_{2}$ fertilization could compensate for the other negative impacts of climate change on crop-weed interaction. Apart from weed biology, weed floral composition, distribution, prevalence, invasiveness, proliferation, and dispersal will be affected by climate change and most likely result in the failure of existing weed management practices. Many seminal reviews $[2,4,22,23]$ confirm the need for reassessment and transformation of current weed control technologies particularly herbicidal control in the context of climate change.

Thus, climate change is likely to have huge impacts on the problematic weeds and their management. Therefore, continuous research is needed to formulate new management strategies to combat them. However, along with climate change, socio-economic, technological, and geopolitical changes will also take place in the 21st century that will likely affect the environment and agricultural systems (including weed management) and our ability to sustain crop productivity. This paper presents a comprehensive review on impact of climate change on weed distribution, growth, biology, and weed management, with indications for formulating new management strategies. The purpose of this review also includes inviting further debate on this issue.

\section{Weed Composition and Distribution}

Climate change is likely to determine the composition, distribution, abundance and dominance of weed species in the arable ecosystems defined and shaped by human intervention [24]. In an arable ecosystem, weed species are highly adapted to ecological eccentricities because of the exposure to different farming activities. Land use, management practices and cropping system mostly govern the characteristics of an arable ecosystem and weeds are closely associated with all these practices $[25,26]$. Since land use and crop management practices are influenced by climatic factors, any change in such will likely influence the occurrence and distribution of weeds [27]. Changing climatic variables will alter crop-weed interactions in favor of weeds, allowing some non-potent weeds to dominate in the arable land. Typically, soil moisture status and ambient temperature are the key 
determinants for weed species composition and distribution but in the context of changing climate, increasing $\mathrm{CO}_{2}$ concentrations is an addition to this list [28].

Although the distribution of most of the troublesome weeds of arable lands are limited to tropical and sub-tropical regions [29], there is possibility of polar-ward expansion [30,31] due to their increased tolerance of many weeds to low temperature under elevated $\mathrm{CO}_{2}$ [32]. In the past, many studies $[33,34]$ predicted that under elevated $\mathrm{CO}_{2}$ conditions, the distribution, abundance, and competitiveness of weeds across the globe will be modified due to increased tolerance to environmental stresses, such as extreme temperatures and drought, and this has now become a reality. Temperature is the primary factor determining weed distribution across the globe, particularly at higher latitudes. Elevated temperatures coupled with heavy precipitation may favor vigorous growth of some weed species, which are currently limited by low temperatures [8]. Increased temperature would expose temperate arable zone to some aggressive tropical colonizing species-particularly $\mathrm{C}_{4}$ grasses [33]. Thus, increased temperature may cause northwards and southwards range shift of tropical and sub-tropical $C_{4}$ species. Boese et al. [32] on the other hand, confirmed increased tolerance of several chilling sensitive tropical/sub-tropical species to low temperatures under elevated $\mathrm{CO}_{2}$ condition.

It is likely that under conditions of elevated temperature and drought, $\mathrm{C}_{4}$ weeds will dominate $\mathrm{C}_{3}$ crops. Although $\mathrm{C}_{3}$ weeds may dominate under increased $\mathrm{CO}_{2}$ conditions; whereas, under the conditions of both elevated $\mathrm{CO}_{2}$ and temperature $\mathrm{C}_{4}$ weeds may be the dominated ones [35]. As predicted by Ziska et al. [36], weedy rice (Oryza sativa f. spontanea) will compete more strongly with cultivated rice while Phalaris minor infestation is expected to worsen in wheat fields under elevated atmospheric $\mathrm{CO}_{2}$ conditions [37]. Apart from geographical distribution, climate change might interfere with weed population biology [38], resulting in a shift to new areas with higher altitudes and latitudes [31]. As documented by many researchers [34,39], increased $\mathrm{CO}_{2}$ levels may increase the ability of plants to tolerate both high and low temperatures which is likely to enable weeds to benefit under climate change at the expense of less "weedy" species. An increase in parasitic weed infestations due to increased ambient $\mathrm{CO}_{2}$ levels would become a serious problem for rice and sorghum crops under rainfed agriculture [40]. Similarly, increased mortality and reduced regeneration of tree species in forests due to increased abundance of woody vines, as a consequence of increased $\mathrm{CO}_{2}$ levels, has been reported worldwide [41] Apart from arable land weeds, several exotic invasive weed species may invade arable lands due to climate change [31] because such species often benefit from carbonaceous fertilization $[42,43]$. Thus, under a climate change scenario, introduction of non-native weeds to arable regions may pose ecological and environmental hazards [44] with serious threat to agricultural productivity. It is evident from different studies $[33,34,45]$ that increased $\mathrm{CO}_{2}$ levels improves plants' ability to tolerate environmental stresses (like drought and temperature stresses) which might modify the distribution of weeds and their interactions in natural and disturbed habitats.

\section{Weed Demography}

Climate change may alter weed demography (population and spread) through differential selective pressures on floristic composition, changes in abiotic and biotic aspects of the agro-ecosystem and intervened changes in crop management practices [46]. As evident from two studies [47,48], weed growth (plant height, leaf production etc.) and prolificacy (seed production) are altered by high temperatures and elevated $\mathrm{CO}_{2}$ levels directly affecting the selection pressure. Carbon dioxide-induced stimulation of growth and seed production have been documented for both cropland and invasive weeds [49-51]. Gealy et al. [52] reported that increased $\mathrm{CO}_{2}$ levels stimulated plant height of weedy (red) rice, a characteristic that is closely associated with seed dispersal efficiency [53].

Similar to the response to $\mathrm{CO}_{2}$, growth, seed production, and germination of weeds are also influenced by changes in temperature [54]. Thus, variations in climatic parameters, especially $\mathrm{CO}_{2}$ and temperature, directly interfere with the evolutionary selection 
of plant species in a mixed community [55]. Thomas et al. [56] opined that differential movement, extinction of native species, and changes in disturbance regimes are the driving forces behind plant community changes in rangeland or forests. As revealed by Early et al. [57], changes in fire regimes due to introduction and spread of downy brome (Bromus tectorum L.), a flammable weed species, are expected to be widespread leading to a dramatic shift in floristic composition and strong selection pressure on existing species. Any changes in the management practices and cropping system, e.g., inclusion of a new crop better suited to changed climate [58] can also bring changes in selection pressure and weed demography. A recent report confirms that local adaption is not less common in introduced weeds than in crop species, rather invasive species are just as locally adapted as native species [59]. This finding is very alarming.

\section{Weed Species Shift}

Weed species shift is an important outcome of climate change in agroecosystems that affect weed management strategies and agricultural productivity. Under the projected climate change scenarios, plant species either have to adapt in situ to the new settings or undergo shifts in their distribution to more favorable conditions. In a composite stand of weeds and crops in an arable ecosystem, shift dynamics of the weed populations in favor of specific species is expected over time [60]. According to Pautasso et al. [24], plant species have three options to avoid extinction: (a) migration with a favorable climate through dispersion mechanisms; (b) acclimation to changes in climate conditions by using their phenotypic plasticity; or (c) adaptation to changes in climate conditions through evolutionary adjustments. In order to persist in a local habitat, species have to respond to the changes in the environment [61] that lead to shifts in weed flora, expansion of their range and thus spreading to new areas [35]. Climate change may bring three distinct types of shifts occurring at different scales: (i) range shifts at the landscape scale; (ii) niche shifts at the community scale; and (iii) trait shifts of individual species at the population scale [62].

Ample prediction and examples of weed species shifts due to changing temperatures have been reported in the literature. Increasing temperature may allow many weed species to invade higher latitudes or altitudes. Many tropical warm-season crops and associated weed species are likely to expand northward due to warming [63]. As anticipated, northward expansion of cogon grass (Imperata cylindrica) and witchweed (Striga asiatica) are now evident [64]. Another interesting example of northward expansion of weed species is that of kudzu (Pueraria lobata), a ubiquitous invasive weed, whose latitudinal distribution in USA was limited to the Ohio Valley and the Mason-Dixon line by low winter temperatures but has now spread to northern areas [65]. Patterson [66] reported that itchgrass (Rottboellia cochinchinensis (Lour.) W.D. Clayton), a profusely tillering, robust grass weed, could invade the central Midwest and California with only a $3{ }^{\circ} \mathrm{C}$ warming trend. With an increase in temperature of $3{ }^{\circ} \mathrm{C}$, it is speculated that witchweed, a root parasite of maize, could shift from coastal plains of North and South Carolina and become established in the Corn Belt of the US with devastating consequences. Similarly, global warming could extend the northern limits of weeds, such as Japanese honeysuckle (Lonicera japonica) and kudzu, by several hundred miles [67]. Under the present conditions, distribution of most of the troublesome cropland weeds are limited to tropical and sub-tropical regions [29], but it is predicted that many weed species will expand towards the polar-regions [31] due to increased tolerance to low temperature under elevated $\mathrm{CO}_{2}$ [32].

As predicted a change in snowfall variability would likely intensify the invasion of forbs in mixed-grass prairie ecosystem which in turn could reduce forage availability [68]. An expansion in the geographic range proposed for weeds, such as Lonicera sempervirens L. and Pueraria lobata (Lour.) Merr. are perfect examples of invasive weeds spreading to cropland areas because of climate change [66]. In Australia, lowland weed species like lantana (Lantana camara L.) are expected to move into higher altitude areas, and frostintolerant species, such as rubber vine (Cryptostegia grandiflora $\mathrm{R}$. Br.), could also shift their ranges further south [69]. Bunce [34] predicted that $\mathrm{CO}_{2}$ enrichment will modify the 
distribution and abundance of weeds across the globe because of increased tolerance to environmental stresses like extreme temperature and drought. Besides cropland weeds, many non-native weeds will also benefit from carbonaceous fertilization $[43,70]$ and will be able to extend their geographic ranges as well as invade cropland areas [31].

In the opinion of McDonald et al. [30], if climate change forecasts are truly realized, major endemic arable-land weed species might experience a significant transformation in their host range creating a huge possibility of invasion by exotic invaders. So far, range shift of weed species has received the most interest by agronomists and weed researchers, but very little information is available in the world literature on niche and trait shifts of cropland weeds. Therefore, to develop adaptive weed management strategies, trait-climate relationships and species interactions should be given due consideration when modeling the possible future distribution of weed species [71,72]. Moreover, as temperature effect is aggravated by moisture stress (drought or submergence), understanding the interaction of temperature and moisture is important for predicting weed species shift due to global warming.

\section{Weed Invasion}

Movement of many weed species from their native range to new areas naturally and/or by human activities often makes some non-native species invasive with negative impact on native species of arable ecosystem [73]. As per literature, approximately 10\% of introduced species become invasive in their new environments, which poses a huge threat to ecosystems and biodiversity [74]. It is predicted that climate change will provide the opportunity for weeds to invade new ecosystems. Climate change is likely to enhance the adaptability of the introduced plants to the new host range and increasing the risk of invasion in native and managed ecosystems [75], as they are well suited to new environments and more successful in resource utilization in elevated $\mathrm{CO}_{2}$ concentrations [35] Genetic variability, different biotic and abiotic or climatic factors with which plants interact determine the invasive nature of a plant species. Genetic factors, among others, include photosynthetic pathway, propagule production and dispersal, seed dormancy, seed bank longevity, herbivore tolerance, while climatic factors include temperature, $\mathrm{CO}_{2}$ concentration, precipitation, etc. [74]. Interactions between climate change and management practices (such as land use) may also turn a benign species into an invasive one with high potential to spread widely causing huge impact on agricultural productivity [76].

There is evidence that weeds can be highly responsive to increased $\mathrm{CO}_{2}$ concentrations that may select for invasiveness within assemblage of plants. Singh and Singh [77] observed extensive coverage of fallow cultivated land by Parthenium hysterophorus during summer season, which might be due to more seed production in hot summer days. Thus, increased temperature may enhance fecundity of weeds and facilitate spread of invasive weeds to new areas [78]. Many studies have highlighted that novel environment resulting from climate change may or may not benefit invasive species, especially when increased resource utilization capability is not consistent under elevated temperature, $\mathrm{CO}_{2}$ levels and precipitations [79]. However, the increased risk of invasiveness under elevated $\mathrm{CO}_{2}$ concentrations alone has been confirmed. Therefore, it is difficult to assess the risk of plant invasiveness under multiple simultaneous change in climatic factors like $\mathrm{CO}_{2}$, temperature and precipitation. Understanding the mechanisms behind the success of weeds to invade new areas will be helpful to tackle this issue.

\section{Weed Growth}

\subsection{Effect of Elevated Atmospheric $\mathrm{CO}_{2}$}

Carbon dioxide is the sole source of carbon for photosynthesis. The current atmospheric $\mathrm{CO}_{2}$ concentration is sub-optimal for photosynthesis in $\mathrm{C}_{3}$ plants. Due to carbon losses through photorespiration $C_{3}$ plants exhibit lower photosynthesis rates compared to $\mathrm{C}_{4}$ plants. On the other hand, $\mathrm{C}_{4}$ plants have a unique internal biochemical pumping mechanism for concentrating $\mathrm{CO}_{2}$ at the carboxylation site and thereby eliminates 
carbon loss by photorespiration $[80,81]$. Under increased atmospheric $\mathrm{CO}_{2}$, there would be stimulation in leaf photosynthesis in $\mathrm{C}_{3}$ plants by increasing the $\mathrm{CO}_{2}$ level in the leaf interior and by decreasing the loss of $\mathrm{CO}_{2}$ by photorespiration [82]. The general consensus is that $\mathrm{C}_{3}$ plants will benefit more through increased leaf area and biomass production than $\mathrm{C}_{4}$ plants from increased $\mathrm{CO}_{2}$ levels. Therefore, it is predicted that $\mathrm{C}_{3}$ weeds, such as parthenium (Parthenium hysterophorus L.) and chromolaena (Chromolaena odorata (L.), will be more aggressive under raised $\mathrm{CO}_{2}$ level [8]. However, the variations in response to $\mathrm{CO}_{2}$ (within a species and between species) are dependent on temperature, light, moisture and nutrient availability [66]. Moreover, $\mathrm{C}_{4}$ species are more heat and moisture tolerant, and therefore the simple perception that increased $\mathrm{CO}_{2}$ levels will only benefit $\mathrm{C}_{3}$ plants may not be true always.

Ziska and Bunce [83] confirmed from a study with six $\mathrm{C}_{4}$ weeds and four $\mathrm{C}_{4}$ crop species that $\mathrm{C}_{4}$ plants may respond directly to elevated $\mathrm{CO}_{2}$ level, and the photosynthetic increase in some $\mathrm{C}_{4}$ weeds (e.g., Amaranthus retroflexus), could be similar to those for $\mathrm{C}_{3}$ species. O'Donnell and Adkins [84] observed that $\mathrm{C}_{3}$ weed wild oat grown at $480 \mathrm{ppm} \mathrm{CO}_{2}$ produced $44 \%$ more seed than those grown at $357 \mathrm{ppm}$. Elevated $\mathrm{CO}_{2}$ resulted in increased growth and biomass accumulation by the $\mathrm{C}_{4}$ weed Amaranthus viridis [81]. Significant increases in photosynthesis and decreases in stomatal conductance were observed in the $C_{3}$ weed Chenopodium album, but no change was observed in the $\mathrm{C}_{4}$ weed Amaranthus retroflexus at elevated $\mathrm{CO}_{2}$ levels [85]. As predicted by Ziska et al. [70], the weeds propagated by roots, stolon, etc., may show a strong response to elevated $\mathrm{CO}_{2}$ level. Moreover, some weeds affect human health through mechanical injury, allergenic reactions, skin irritations or internal poisoning [86]. Changes in biology of those weeds as the consequence of increased $\mathrm{CO}_{2}$ levels may alter their toxicity [4]. For example, changes in pollen production and allergenicity in common ragweed (Ambrosia artemissiifolia L.) was observed due to changes in $\mathrm{CO}_{2}$ level $[87,88]$. However, the mechanism behind the changes in toxicity of secondary compounds associated in weeds due to increased $\mathrm{CO}_{2}$ is still unclear.

\subsection{Effect of Increased Temperature}

Temperature is one of the key factors affecting distribution, growth, development and phenology of plants. This is the reason why a particular species is compatible to a specific temperature zone. Since physiological processes such as photosynthesis, respiration and transpiration are highly temperature dependent any changes in temperature might affect plant growth. Compared to vegetative stages reproductive stage is more sensitive to temperature changes. Like other plants weeds also respond to temperature changes and adapt strategies to cope with temperature extremes. In case of unfavorable temperature, weed species either have to adapt or undergo shifts to more favorable conditions. Weed shift due to temperature change predicted earlier is now reality. In the context of climate change, our concern is only increased temperature since $2.4-6.4{ }^{\circ} \mathrm{C}$ increase in global average temperature is predicted by the end of 21st century [89]. In general, due to global warming, weeds are often able to expand their range into new areas, and to higher latitudes or altitudes. Because $\mathrm{C}_{4}$ plants are more tolerant to elevated temperature, weeds with a $\mathrm{C}_{4}$ photosynthetic pathway may be more competitive compared with weeds possessing a $C_{3}$ photosynthetic pathway $[83,90]$. Elevated temperature is likely to cause different physiological changes in weeds, such as shortening vegetative phase and life cycle, reduced tillering, assimilate availability, decreasing duration and rate of seed filling, and higher oxidative damage [91]. As observed by O'Donnell and Adkins [84], wild oat grown at higher temperature completed their development faster compared to normal temperature and faster maturation relative to the crop would result in wild oat rich soil seed bank. Tunget et al. [92] recorded higher growth and root: shoot ratios in summer weed species Sida spinosa (prickly sida) at elevated temperature. As predicted, a change in snowfall variability would intensify the invasion of forbs in mixed-grass prairie ecosystems, which in turn could reduce forage availability [68]. 


\subsection{Effect of Changes in Precipitation}

Water is one of the limiting factors for plant growth. Every species requires specific moisture regimes for optimum growth, beyond which growth and development are reduced or even stopped in extreme cases. As a consequence of climate change drought, flood and erratic rainfall are likely to happen frequently causing moisture stress in nonarable and arable land ecosystems. This will make both crops and weeds vulnerable. Due to greater physiological plasticity and intra specific genetic variation (compared to crops) weeds are believed to be less vulnerable to drought and submergence conditions, but will definitely respond to moisture stress. The responses are species and condition dependent. Some weeds release allelochemicals under drought condition to thrive well and compete against crops under stress [66]. Submergence favors $C_{3}$ weeds, while drought favors $C_{4}$ weeds. This is why, $C_{3}$ weeds are dominant in submerged conditions, but $C_{4}$ weeds are dominant in dry land soils [93]. It is evident [94] that water stress increased leaf area and biomass production of $\mathrm{C}_{4}$ grasses like Echinochloa crus-galli, Eleusine indica and Digitaria ciliaris. Drought adapted rangeland weed species like cheat grass (Bromus tectorum) and yellow star thistle (Centaurea solstitialis) increase seed production when soil moisture is sufficient after prolonged and heavy winter [66]. Interestingly their drought adoption mechanisms are totally different; cheat grass avoid drought by shortening life span, while thistle combats drought using deeper root system. Greater herbivore tolerance in invasive Alternanthera philoxeroides was found under moisture stress, while for the native congener Alternanthera sessilis the same was reduced [95]. Thus, changes in precipitation might have huge impact on weed composition and growth.

\section{Crop-Weed Competition and Interaction}

Nature of crop-weed interactions mostly depend on climatic variables (temperature, $\mathrm{CO}_{2}$, precipitation etc.), photosynthetic pathways of the component species, edaphic conditions, resource availability, and management practices. Furthermore, any changes in one of the climatic variables will alter other factors affecting the outcome of cropweed interactions. Other than climate, photosynthetic pathway is the most important factor that determines the outcome of crop-weed interactions. The $C_{3}$ and $C_{4}$ species interact differentially between themselves depending on their relative proportions. The following conditions may be encountered in crop-weed interaction under field conditions: (a) $C_{3}$ crops competing with both $C_{3}$ and $C_{4}$ weeds where $C_{3}$ weeds are dominant; (b) $C_{3}$ crops competing with both $C_{3}$ and $C_{4}$ weeds where $C_{4}$ weeds are dominant; (c) $C_{4}$ crops competing with both $C_{3}$ and $C_{4}$ weeds where $C_{3}$ weeds are dominant; and (d) $C_{4}$ crops competing with both $C_{3}$ and $C_{4}$ weeds where $C_{4}$ weeds are dominant [78]. On the other hand, Malarkodi et al. [96] grouped crop-weed combinations in arable ecosystems into the following four categories: (a) $C_{4}$ weeds in $C_{3}$ crops; (b) $C_{3}$ weeds in $C_{3}$ crops; (c) $\mathrm{C}_{3}$ weeds in $\mathrm{C}_{4}$ crops; and (d) $\mathrm{C}_{4}$ weeds in $\mathrm{C}_{4}$ crops. However, in practical situations weed populations are always composite. The outcome of competition and/or interaction between crop and weed in the changing climate is very difficult to predict. Being troublesome invaders, ecological opportunist and resilient plants, weeds are more likely to benefit from crop-weed interactions in a changing environment. Due to the differential responses of crops and weeds, the outcomes of climate change on the arable ecosystem are variable. The outcome is determined by species population and composition, carbon fixation pathway of dominant species, and crop-weed interactions. However, it is generally accepted that atmospheric $\mathrm{CO}_{2}$ enrichment is likely to stimulate the growth of plants, and $\mathrm{C}_{3}$ plants are the most likely to benefit.

In general, elevated $\mathrm{CO}_{2}$ levels would stimulate the growth of only $\mathrm{C}_{3}$ crops but the growth of both $\mathrm{C}_{3}$ and $\mathrm{C}_{4}$ weeds. This will lead to increased crop-weed competition and crop yield reduction, negating the positive impact of $\mathrm{CO}_{2}$ "fertilization" on the productivity of major $\mathrm{C}_{3}$ crops [8]. Although both temperature and $\mathrm{CO}_{2}$ levels are increasing simultaneously, most studies have focused on the response of crop and weed to elevated temperature or $\mathrm{CO}_{2}$ separately. Very few studies have attempted to predict the possible 
interaction effects of these two important climatic variables on crop-weed competition. Alberto et al. [97] concluded that the $C_{3}$ crop rice had a competitive advantage over a $\mathrm{C}_{4}$ weed, Echinochloa glabrescens when elevated $\mathrm{CO}_{2}$ level was the only consideration, while this weed species had a competitive advantage over the rice crop when both elevated $\mathrm{CO}_{2}$ and elevated temperature were considered. Therefore, the outcome of the crop-weed interaction depends on the number of climatic variables taken into consideration.

It is evident from different studies [33,34] that increased $\mathrm{CO}_{2}$ levels help plants tolerate environmental stresses (like drought and temperature stresses) better and this might modify the inter-specific interactions in natural and disturbed habitats. Increased environmental stresses make crops highly vulnerable to biotic stresses like insect and disease infestation. However, more physiological plasticity and greater intra-specific genetic variation (compared to crops) enables weeds to tolerate both biotic and abiotic stresses. Hence, weeds will be able to gain a stronghold in the changing environment compared to crops [78]. Any environmental stress makes crop more vulnerable to insect and disease infestations resulting in reductions in their ability to compete with weeds [66]. Long-term observations showed that the worst weed species in a given crop species are similar in growth habit and photosynthetic pathway because in most of the cases the weed species is the wild/uncultivated species of the crop, for example, the weed red rice in rice, wild oats in oat. Unfortunately, where photosynthetic pathway is the same, growth of the weed species is favored by $\mathrm{CO}_{2}$ enrichment [4]. As predicted by Carter and Peterson [98], a global rise in ambient $\mathrm{CO}_{2}$ level would alter the competitive balance between $\mathrm{C}_{3}$ and $\mathrm{C}_{4}$ plants, species distribution patterns, and net productivity of the mixed communities.

In general, $\mathrm{C}_{4}$ plants are more productive than $\mathrm{C}_{3}$ plants under optimal temperature and ambient $\mathrm{CO}_{2}$ level, but higher $\mathrm{CO}_{2}$ concentration may alter the scenario [99]. A survey of 27 non-crop $C_{3}$ species confirmed $79-272 \%$ increased biomass accumulation under elevated $\mathrm{CO}_{2}$ level [66]. While under drought situation, elevated $\mathrm{CO}_{2}$ might favor $\mathrm{C}_{4}$ plants more than $\mathrm{C}_{3}$ plants [100]. CAM plants' reaction to increased $\mathrm{CO}_{2}$ levels is similar to $C_{3}$ plants under optimum moisture, but similar to $C_{4}$ plants under water stress [101]. In the case of perennial weeds, $\mathrm{CO}_{2}$ enrichment is likely to stimulate tuber and rhizome growth, and in the process their competitiveness, abundance and survivability in arable ecosystem [8], doubling the ambient $\mathrm{CO}_{2}$ levels may cause a $10-50 \%$ yield increase in $C_{3}$ crops (e.g., rice, wheat, and soybean) but only $0-10 \%$ in $C_{4}$ crops (e.g., maize, sorghum, and sugarcane) depending on the growing conditions and availability of water and nutrients [102]. Moya et al. [103] reported that elevated $\mathrm{CO}_{2}$ alone compared to elevated $\mathrm{CO}_{2}$ along with increased ambient temperature resulted in reduced rice yield. Thus, simultaneous exposure to increased $\mathrm{CO}_{2}$ level and temperatures may negate the increased grain yield under $\mathrm{CO}_{2}$ enrichment. A global rise in $\mathrm{CO}_{2}$ could also modify photosynthesis and stomatal physiology and thus the competitive balance of a crop-weed mixture in the arable ecosystem [93]. Due to climate change, weed species with less phenotypic plasticity are likely to experience population decline due to frequent extreme weather events like drought [62]. On the other hand, some more resilient droughttolerant weeds species may invade bare arable areas created by limited growth of crops or pastures as a consequence of erratic rainfall and prolonged drought [4].

As shown in Table 1 , of the 10 major crops, 7 have the $C_{3}$ photosynthetic pathway [104]. In contrast, 7 of the 10 "World's Worst Weeds" are $C_{4}$ plants [105]. It is alarming that in a $\mathrm{CO}_{2}$ enriched atmosphere, important $\mathrm{C}_{4}$ crops may become more vulnerable to increased competition from $\mathrm{C}_{3}$ weeds [106]. Some examples of different crop-weed interaction under climate change are also summarized in Table 2. 
Table 1. List of world major crops and noxious weeds with their photosynthetic pathways.

\begin{tabular}{|c|c|c|c|c|c|c|c|}
\hline \multicolumn{4}{|c|}{ Major Crops [104] } & \multicolumn{4}{|c|}{ Noxious Weeds [105] } \\
\hline $\begin{array}{l}\text { Common } \\
\text { Name }\end{array}$ & Scientific Names & $\begin{array}{l}\text { Family } \\
\text { Names }\end{array}$ & $\begin{array}{l}\text { Photosynthetic } \\
\text { Pathways }\end{array}$ & $\begin{array}{l}\text { Common } \\
\text { Name }\end{array}$ & Scientific Names & $\begin{array}{l}\text { Family } \\
\text { Names }\end{array}$ & $\begin{array}{l}\text { Photosynthetic } \\
\text { Pathways }\end{array}$ \\
\hline Wheat & Triticum aestivum $\mathrm{L}$. & Poaceae & $\mathrm{C}_{3}$ & $\begin{array}{c}\text { Purple } \\
\text { nutsedge }\end{array}$ & Cyperus rotundus L. & Cyperaceae & $\mathrm{C}_{4}$ \\
\hline Corn & Zea mays $\mathrm{L}$. & Poaceae & $\mathrm{C}_{4}$ & Bermuda grass & $\begin{array}{l}\text { Cynodon dactylon } \\
\text { (L.) Pers. }\end{array}$ & Poaceae & $\mathrm{C}_{4}$ \\
\hline Rice & Oryza sativa $\mathrm{L}$. & Poaceae & $\mathrm{C}_{3}$ & Barnyard grass & $\begin{array}{c}\text { Echinochloa } \\
\text { crus-galli (L.) Beauv }\end{array}$ & Poaceae & $\mathrm{C}_{4}$ \\
\hline Soybeans & $\begin{array}{c}\text { Glycine max (L.) } \\
\text { Merr. }\end{array}$ & Fabaceae & $\mathrm{C}_{3}$ & Jungle rice & $\begin{array}{l}\text { Echinochloa colona } \\
\text { (L.) Link }\end{array}$ & Poaceae & $\mathrm{C}_{4}$ \\
\hline Sorghum & $\begin{array}{l}\text { Sorghum bicolor (L.) } \\
\text { Moench }\end{array}$ & Poaceae & $\mathrm{C}_{4}$ & $\begin{array}{l}\text { Indian goose } \\
\text { grass }\end{array}$ & $\begin{array}{l}\text { Eleusine indica (L.) } \\
\text { Gaertn. }\end{array}$ & Poaceae & $\mathrm{C}_{4}$ \\
\hline Cassava & $\begin{array}{l}\text { Manihot esculenta } \\
\text { Crant }\end{array}$ & Euphorbiaceae & $\mathrm{C}_{3}$ & Johnson grass & $\begin{array}{l}\text { Sorghum halepense } \\
\text { (L.) Pers. }\end{array}$ & Poaceae & $\mathrm{C}_{4}$ \\
\hline Potatoes & Solanum tuberosum $\mathrm{L}$. & Solanaceae & $\mathrm{C}_{3}$ & Cogon grass & $\begin{array}{l}\text { Imperata cylindrica } \\
\text { (L.) Raeuschel }\end{array}$ & Poaceae & $\mathrm{C}_{4}$ \\
\hline Yams & Dioscorea alata $\mathrm{L}$. & Dioscoreaceae & $\mathrm{C}_{4}$ & Water hyacinth & $\begin{array}{l}\text { Eichhornia crassipes } \\
\text { (Mart.) Solms }\end{array}$ & Pontederiaceae & $\mathrm{C}_{3}$ \\
\hline $\begin{array}{c}\text { Sweet } \\
\text { potatoes }\end{array}$ & $\begin{array}{l}\text { Ipomoea batatas (L.) } \\
\text { Lam. }\end{array}$ & Convolvulaceae & $\mathrm{C}_{3}$ & Purselane & Portulaca oleracea L. & Portulacaceae & $\begin{array}{l}\mathrm{C}_{3}-\mathrm{C}_{4} \text { inter- } \\
\text { mediates }\end{array}$ \\
\hline Plantains & Musa $\times$ paradisiaca & Musaceae & $\mathrm{C}_{3}$ & Lambsquarters & Chenopodium album $\mathrm{L}$. & Chenopodiaceae & $\mathrm{C}_{3}$ \\
\hline
\end{tabular}

Table 2. Crop-weed interaction outcome at elevated temperature and $\mathrm{CO}_{2}$ level.

\begin{tabular}{|c|c|c|c|c|c|}
\hline \multicolumn{2}{|c|}{ Interaction between } & \multirow{2}{*}{ Exposed Conditions } & \multirow{2}{*}{ Outcome } & \multirow{2}{*}{ Remarks } & \multirow{2}{*}{ Reference } \\
\hline Crop Species & Weed Species & & & & \\
\hline $\begin{array}{c}\text { Rice } \\
(\text { Oryza sativa })\left(\mathrm{C}_{3}\right)\end{array}$ & $\begin{array}{c}\text { Red rice } \\
\text { (Oryza sativa f. } \\
\text { spontanea) }\left(\mathrm{C}_{3}\right)\end{array}$ & $\begin{array}{l}\text { Increased } \mathrm{CO}_{2} \text { levels } \\
\text { up to } 500 \mathrm{ppm}\end{array}$ & $\begin{array}{l}\text { (i) Rice biomass increased with } \\
\text { increase in } \mathrm{CO}_{2} \text { up to } 400 \mathrm{ppm} \\
\text { (ii) Red rice biomass and seed } \\
\text { production increased up to } \\
500 \mathrm{ppm}\end{array}$ & $\begin{array}{l}\text { Red rice is more } \\
\text { competitive than } \\
\text { cultivated rice under } \\
\text { elevated } \mathrm{CO}_{2} \text { levels }\end{array}$ & $\begin{array}{c}\text { Ziska et al. } \\
{[36]}\end{array}$ \\
\hline $\begin{array}{c}\text { Rice } \\
(\text { Oryza sativa })\left(\mathrm{C}_{3}\right)\end{array}$ & $\begin{array}{l}\text { Echinochloaglabrescens } \\
\text { L. }\left(\mathrm{C}_{4}\right)\end{array}$ & $\begin{array}{c}\text { Two different } \mathrm{CO}_{2} \\
\text { concentrations }(393 \\
\left.\text { and } 594 \mu \mathrm{L} \mathrm{L} \mathrm{L}^{-1}\right) \\
\text { under day } / \text { night } \\
\text { temperatures of } \\
27 / 21^{\circ} \mathrm{C} \text { and } \\
37 / 29^{\circ} \mathrm{C}\end{array}$ & $\begin{array}{l}\text { (i) In monoculture, increasing } \\
\text { the } \mathrm{CO}_{2} \text { concentration, at } \\
27 / 21^{\circ} \mathrm{C} \text {, significantly } \\
\text { increased biomass }(+47 \%) \\
\text { and seed yield }(+55 \%) \text { of rice } \\
\text { but not those of } \mathrm{C}_{4} \text { weed } \\
\text { (ii) When grown in mixture, } \\
\text { at elevated } \mathrm{CO}_{2} \text { level and } \\
27 / 21^{\circ} \mathrm{C} \text {, rate of increase in } \\
\text { rice biomass was more than } \\
\text { that of } \mathrm{C}_{4} \text { weed; while at } \\
\text { elevated } \mathrm{CO}_{2} \text { level and } \\
37 / 29^{\circ} \mathrm{C} \text {, rate of increase in } \\
\text { rice biomass was less than } \\
\text { that of } \mathrm{C}_{4} \text { weed }\end{array}$ & $\begin{array}{l}\mathrm{A}_{3} \text { crop may } \\
\text { compete better } \\
\text { against a } \mathrm{C}_{4} \text { weed at } \\
\text { elevated } \mathrm{CO}_{2} \text { alone, } \\
\text { but simultaneous } \\
\text { increases in } \mathrm{CO}_{2} \text { and } \\
\text { temperature could } \\
\text { favor a } \mathrm{C}_{4} \text { weed }\end{array}$ & $\begin{array}{c}\text { Alberto et al. } \\
\text { [97] }\end{array}$ \\
\hline $\begin{array}{c}\text { Soybean } \\
\text { (Glycine max) }\left(\mathrm{C}_{3}\right)\end{array}$ & $\begin{array}{c}\text { Lambsquarters } \\
\text { (Chenopodium album) } \\
\left(\mathrm{C}_{3}\right) \text { and } \\
\text { Amaranthus } \\
\text { retroflexus }\left(\mathrm{C}_{4}\right)\end{array}$ & $\begin{array}{c}\text { Amibient and } \\
\text { elevated } \mathrm{CO}_{2} \\
\text { (ambient }+250 \text { ppm) }\end{array}$ & $\begin{array}{l}\text { (i) Soybean yield ( } 23 \%) \\
\text { increased when grown in } \\
\text { monoculture due to increased } \\
\qquad \mathrm{CO}_{2} \text { level } \\
\text { (ii) However, when grown } \\
\text { with C. album, soybean yield } \\
\text { reduction increased from } 28 \% \\
\text { at ambient } \mathrm{CO}_{2} \text { to } 39 \% \text { at } \\
\text { elevated } \mathrm{CO}_{2} \\
\text { (iii) When grown with } \mathrm{A} \text {. } \\
\text { retroflexus, soybean yield } \\
\text { diminished from } 45 \% \text { to } 30 \% \\
\text { at elevated } \mathrm{CO}_{2} \text { compared to } \\
\text { ambient } \mathrm{CO}_{2}\end{array}$ & $\begin{array}{l}\text { Under elevated } \mathrm{CO}_{2} \text {, } \\
\text { C. album would be } \\
\text { benefited more than } \\
\text { soybean and } A \text {. } \\
\text { retroflexus would be } \\
\text { less benefitted. Thus, } \\
\text { C. album could } \\
\text { become more } \\
\text { dominating weed. }\end{array}$ & Ziska [107] \\
\hline
\end{tabular}


Table 2. Cont.

\begin{tabular}{|c|c|c|c|c|c|}
\hline \multicolumn{2}{|c|}{ Interaction between } & \multirow{2}{*}{ Exposed Conditions } & \multirow{2}{*}{ Outcome } & \multirow{2}{*}{ Remarks } & \multirow{2}{*}{ Reference } \\
\hline Crop Species & Weed Species & & & & \\
\hline $\begin{array}{l}\text { Sorghum } \\
\text { (Sorghum halepense } \\
\text { (L.) Pers }\left(\mathrm{C}_{4}\right)\end{array}$ & Festuca elatior $\mathrm{L} .\left(\mathrm{C}_{3}\right)$ & $\begin{array}{c}\text { Ambient } \mathrm{CO}_{2} \text { levels } \\
\text { and elevated } \mathrm{CO}_{2}\end{array}$ & $\begin{array}{l}\text { Festuca elatior out-competed } \\
\text { Sorghum at both ambient and } \\
\text { elevated } \mathrm{CO}_{2} \text { levels. }\end{array}$ & $\begin{array}{l}\mathrm{A} \mathrm{C}_{3} \text { weed can be } \\
\text { benefitted more than } \\
\text { a } \mathrm{C}_{4} \text { at increased } \\
\mathrm{CO}_{2} \text { levels }\end{array}$ & $\begin{array}{c}\text { Carter and } \\
\text { Peterson [98] }\end{array}$ \\
\hline $\begin{array}{l}\text { Sorghum } \\
\text { (Sorghum halepense } \\
\text { (L.) Pers }\left(\mathrm{C}_{4}\right)\end{array}$ & $\begin{array}{l}\text { Velvetleaf }(\text { Abutilon } \\
\text { theophrasti) }\left(\mathrm{C}_{3}\right) \text { and } \\
\text { Redroot pigweed } \\
\text { (Amaranthus } \\
\text { retrojlexus) }\left(\mathrm{C}_{4}\right)\end{array}$ & $\begin{array}{l}\text { Ambient } \mathrm{CO}_{2} \text { levels } \\
\text { and elevated } \mathrm{CO}_{2}\end{array}$ & $\begin{array}{c}\text { Both crop-weed interactions } \\
\text { resulted in increased weed } \\
\text { biomass and reduced } \\
\text { sorghum yield loss at } \\
\text { elevated } \mathrm{CO}_{2}\end{array}$ & $\begin{array}{c}\text { Elevated } \mathrm{CO}_{2} \text { level } \\
\text { favors both } \mathrm{C}_{3} \text { and } \\
\mathrm{C}_{4} \text { weeds compared } \\
\text { to a } \mathrm{C}_{4} \text { crop } \\
\text { like sorghum }\end{array}$ & Ziska [108] \\
\hline
\end{tabular}

\section{Resource Utilization Efficiency by Weed}

Growth, productivity, and survivability of a plant largely depends on its resource utilization capacity that is mostly determined by its genetic makeup. In an arable-land ecosystem, inter-specific (crop vs. weed) and intra-specific (among densely populated crop-weed plants) competition for limited resources, such as nutrients and water, is very common. In a changing climate, this competition would be more severe and might be the key determinant of survivability for the native and non-native species. Being a colonizing opportunist with wide ecological amplitudes, weeds are more likely to have an advantage in utilization of limited resources in the changing environment than crops.

Photosynthetic pathway plays the key role in the efficient utilization of limited resources. The $\mathrm{C}_{4}$ plants enjoy an advantage under hot and arid condition resulting in higher water use efficiency over $C_{3}$ plants. Patterson [94], observed that $C_{4}$ grasses like Eleusine indica, Echinochloa crus-galli and Digitaria ciliaris produced higher leaf area and biomass due to $\mathrm{CO}_{2}$ enrichment, even under water stress conditions. Thus, similar to $\mathrm{C}_{3}$ plants, $\mathrm{C}_{4}$ plants also will show growth stimulation with higher ambient $\mathrm{CO}_{2}$ levels posing a huge threat to $\mathrm{C}_{4}$ weed management. Generally, $\mathrm{C}_{4}$ plants are dominant in dry land soils and $C_{3}$ plants in submerged soils. Under present conditions, flood irrigated lowland rice enjoys less competition from $\mathrm{C}_{4}$ weeds, while upland and rainfed lowland rice face severe competition from $\mathrm{C}_{4}$ weeds [93]. Changes in the amount and rainfall pattern due to climate change may alter the scenario demanding new weed management strategies for rice.

There are evidences that increased $\mathrm{CO}_{2}$ concentrations lowers plant water requirements by reducing transpiration rate, while promoting photosynthesis. Carlson and Bazzaz [109] reported that ambient $\mathrm{CO}_{2}$ enrichment from 300 to $600 \mathrm{ppm}$ increased water use efficiency (WUE) of soybean $\left(C_{3}\right)$ and corn $\left(C_{4}\right)$ by $48 \%$ and $54 \%$, respectively, conversely the same recorded for a $\mathrm{C}_{3}$ weed, velvetleaf (Abutilon theophrasti) and a $\mathrm{C}_{4}$ weed redroot pigweed (Amaranthus retroflexus) were $87 \%$ and $76 \%$, respectively. This confirms greater stimulation of WUE in these weeds than in the crops due to $\mathrm{CO}_{2}$ enrichment. As reported by Kimball and Idso [110], two-fold enrichment of $\mathrm{CO}_{2}$ level increased WUE of both $\mathrm{C}_{3}$ and $C_{4}$ species by $70-100 \%$ through reducing transpiration losses as much as $25-40 \%$ as a consequence of reduced stomatal aperture by 30-40\%. In another study, Drake et al. [111] recorded evapotranspiration (ET) reduction by $17-22 \%$ in the $C_{3}$ and $28-29 \%$ in the $C_{4}$ community at elevated $\mathrm{CO}_{2}$. However, leaf area index (LAI) is another important factor determining water saving from $\mathrm{CO}_{2}$ enrichment. Despite increased WUE due to $\mathrm{CO}_{2}$ enrichment in both $C_{3}$ and $C_{4}$ species water saving is expected only when increase in LAI is more than decreases in stomatal conductance [8]. Hence, with the changing climate, many weed species are likely to grow better and invade moisture limited environment. Apart from WUE, nutrient availability by plants is also reported to be altered due to changes in climate. Zhang et al. [112] recorded reduction in nitrogen availability due to increased $\mathrm{CO}_{2}$ concentration. Nitrogen and phosphorus availability become limiting due to increased $\mathrm{C}$ : $\mathrm{N}$ ratio in plant leaves under $\mathrm{CO}_{2}$ enrichment [113]. Furthermore, $\mathrm{C}_{4}$ plants have higher nutrient use efficiency than $\mathrm{C}_{3}$ plants, and reduced nitrogen availability has been shown to favor $C_{4}$ plants than $C_{3}$ plants [114]. Therefore, climate change might alter the plant 
community structure, abundance of specific weed species, and more likely $\mathrm{C}_{4}$ weeds will dominate over $C_{3}$ ones. However, prediction of the differential responses of $C_{3}$ and $C_{4}$ weeds in terms of water and nutrient use efficiencies to changes in $\mathrm{CO}_{2}$ level, temperature and water availability are difficult as our knowledge on this complex issue is still rudimentary. All these issues require critical considerations for predicting the stimulation of weed growth as an outcome of climate change. But certainly, nutrient and water dynamics under changing climate must be considered as an important issue in weed management research.

\section{Weed Management}

\subsection{Herbicide Efficacy}

As it is increasingly clear, climate is likely to alter the success of herbicidal weed management [2]. Climatic factors like temperature, $\mathrm{CO}_{2}$, soil moisture, wind speed, etc. might influence herbicide coverage, persistence, mode of action, efficacy and selectivity [115]. The efficacy of a particular herbicide is temperature dependent. Prolonged high temperatures may reduce the efficacy and alter selectivity of both pre- and post-emergence herbicides [116,117]. Even a selective herbicide may become non-selective under temperature higher than optimum [5]. Moreover, under elevated temperatures increased growth rate of plants may result in narrower temporal windows of herbicide spraying opportunity before critical crop-weed competition period starts [118]. Patterson et al. [119] on the other hand, reported that increased temperature along with increased metabolic activities tend to increase uptake and translocation of many herbicides with the consequence of higher efficacy. Temperature effect on the efficacy of flumetsulam against Raphanus raphanistrum [116], and clodinafop-propargil against Avena spp. [117] is evident. Less persistence of herbicide due to faster degradation under increased temperature was reported by Bailey [115], making weed control complicated in autumn and winter; conversely, slow herbicide degradation in summer caused carry-over problems. It is recognized that increased temperature leads to reduced protein levels in plant tissues [120] resulting in less demand for aromatic and branched-chain amino acids, with potential declines in the efficacy of enzyme inhibitor herbicides such as glyphosate [(N-phosphonomethyl) glycine] [121].

Carbon dioxide-induced changes in leaf morphology, anatomy, physiology and root: shoot ratio can affect herbicide uptake, translocation and efficacy [66]. Elevated $\mathrm{CO}_{2}$ can increase leaf cuticular thickness, reduce stomatal number and decrease conductance, possibly limiting the uptake of foliar applied herbicides. As noted by Malarkodi et al. [96], elevated $\mathrm{CO}_{2}$ can affect timing of herbicide application, absorption of foliar applied herbicides, uptake of soil applied herbicides and alter chemical susceptibility of the weeds. Patterson and Flint [122] noted that if increased photosynthesis stimulates higher root, rhizome, or tuber growth due to rise in $\mathrm{CO}_{2}$, perennial weeds will be more abundant resulting in their control by herbicides difficult. Greater increases in biomass will result in dilution of herbicide applied, making weed control more difficult and costly [66]. There are increasing number of studies on declining chemical efficacy of herbicides with rising $\mathrm{CO}_{2}$ [123-125]. In Canada thistle (Cirsium arvense L. Scop.), additional $\mathrm{CO}_{2}$ stimulated root over shoot growth, diluting shoot-applied herbicide and resulted in failure to kill roots and a regeneration of the whole plant [123]. Reduced efficacy of the widely used herbicide glyphosate due to elevated $\mathrm{CO}_{2}$ has been confirmed by many researchers [124,126].

Moisture stress or drought has the potential to reduce herbicide efficacy. Different consequences of drought like decreased stomatal aperture, cuticle thickening, increased leaf pubescence might limit herbicide entry into the leaf with subsequent reduction in herbicide efficacy [5]. Reduced uptake of soil-applied herbicides due to altered transpiration under drought condition is documented. Drought-stress slowed down the vegetative growth of weeds resulting in reduced efficacy of post-emergence/systemic herbicides which requires active plant growth for their translocation and activity. Pre-emergence herbicides, on the other hand, cannot be absorbed by the plant roots and will be unable to reach their target site if soil moisture is not sufficient [78]. As established in [5], wetting and drying of soil profiles might affect microbial activity and herbicide application. Therefore, under moisture stress, 
using higher application rates or adding certain surfactants may be needed to enhance the herbicide efficacy [78]. If optimum soil moisture is not available within a few days after herbicide application, herbicides very often fail to move into the soil (due to degradation by sunlight or microorganisms) to affect weed seed germination and seedling emergence processes resulting in poor weed control [78]. On the other hand, moisture stress may extend the persistence of herbicides due to slower microbial degradation [127]. Conversely, humid and warmer condition might shorten herbicide persistence in the soil [115].

\subsection{Herbicide Resistance}

In recent years, herbicide resistance is of huge concern in chemical weed management and is the main focus of ongoing research. As reported in many studies, climate change contributes to increased herbicide resistance, but how climate change affects the selection and evolution of herbicide resistance in plants has not been extensively studied yet $[128,129]$. Increased glyphosate tolerance in a $\mathrm{C}_{4}$ species, redroot pigweed (Amaranthus retroflexus) and a $\mathrm{C}_{3}$ species, common lambsquarters (Chenopodium album) at elevated $\mathrm{CO}_{2}$ was observed by Ziska et al. [85]. In another study, Ziska et al. [123] reported that the reduced efficacy was a consequence of glyphosate tolerance in Canada thistle (Cirsium arvense) due to a dilution effect and increased root biomass under $\mathrm{CO}_{2}$ enriched environment. It was observed that quackgrass (Elytrigia repens) became more resistant to herbicides when grown under elevated $\mathrm{CO}_{2}$ level, which might be a consequence of faster growth and shorter seedling stage which is the most vulnerable phase [124]. Furthermore, the long-term efficacy of GMO-directed herbicide management strategy is dependent on the stability of the climate. Changes in climate may alter the gene flow and transfer of resistance between the genetically modified crops and associated weeds, depending on the degree of genetic similarity [46]. From a long-term study, Ziska et al. [130] confirmed greater synchronicity in flowering times and enhanced outcrossing rates between a cultivated rice mutant that is resistant to a class of herbicides (imidazolinone, ClearfieldTM 161) and a weedy red rice ascension accession (StgS) with the increase in $\mathrm{CO}_{2}$ levels $(300,400$, and 600 ppm). Consequently, as $\mathrm{CO}_{2}$ increased, the number of weedy herbicide-resistant hybrid progeny also increased [130]. However, the effect of elevated temperature on floral synchrony and gene flow between crops and wild relatives and their consequences on evolution of herbicide resistance is still unclear. Growing herbicide-resistant crops can bring changes in floristic composition of weeds with the consequence of reduced herbicide efficacy due to climate change and could affect weed management strategies in herbicide-resistant crops [78].

Thus far, it is not clear whether or not the response of herbicides to climate change is ubiquitous. However, if this is found to be common and widespread, it will certainly have a significant impact on agriculture demanding frequent applications and/or higher concentrations of herbicide for effective weed control at economic, environmental, and health costs.

\subsection{Mechanical Control}

The impact of climate change on mechanical control of weeds may become apparent through changes in the root: shoot ratio. An increase in $\mathrm{CO}_{2}$ levels may lead to enhanced below ground carbon storage with subsequent increases in the belowground growth (roots or rhizomes) in perennial weeds [131]. An increase in root:shoot ratio coupled with increased root or rhizome growth may make it more difficult to control some perennial weeds that regenerate from root fragments left after mechanical tillage, e.g., Canada thistle (Cirsium arvense) [123]. Examples of some other weeds that may respond in a similar manner are skeletonweed (Chondrilla juncea), and silverleaf nightshade (Solanumelae agnifolium) [132]. Consequently, mechanical tillage may lead to additional plant propagation in a higher $\mathrm{CO}_{2}$ environment, with increased asexual reproduction from below ground structures and negative effects on weed control [123]. Increased disking/harrowing to control such weeds would aggravate the weed problem. 


\subsection{Biological Control}

Biological control of weeds involves the introduction of host-specific agents (such as insects, fungi, herbivores) that feed only on the target plant [117]. Every bio-control system, natural or manipulated, requires a specific environmental condition to perform the best, and therefore changes in climate is likely to affect the bio-control efficacy. Climate change could impact the biology of the agent and/or on the ability of the host to tolerate or compensate for the presence of the herbivore or plant pathogen [35]. Climatic changes may disrupt natural and classical biological control of weeds [78], and could affect its efficacy by altering the morphology, development and reproduction of bio-agents [35]. At the same time, it may provide new opportunities for insect species, such as Ophraella communa, to be used as bio-control agents for weed control [133]. Elevated $\mathrm{CO}_{2}$ levels can alter the profile of secondary compounds in weeds [134] and thus affect weed-herbivore interactions. Furthermore, elevation in $\mathrm{CO}_{2}$ levels might have direct relation with the changes in C:N ratio of weeds and alterations in the feeding habits and growth rate of herbivores [96]. Increase in greenhouse gases might affect the herbivore-plant relationship with impacts on bio-control efficacy at both the spatial and temporal scales [132]. It is evident that drought may result in increased levels of many insect-resistance allelochemicals in some weed species [135]. Since water stress affects the development of both host plants and bio-agents, bio-control might be less effective in drier situations [132]. Changes in temperature may alter the distribution of both bio-agents and target host, e.g., elevated temperature might cause movement of bio-agents from sub-tropical areas to temperate regions to survive on weeds affecting the bio-control system efficacy. Increased temperature is likely to increase the rate of life cycles of both the bio-control agents and host weeds [132]. Patterson [66] warned that warming might increase overwintering of insect populations resulting in changes to their potential range. Climate change may also bring changes in plant nutrient content due to elevated $\mathrm{CO}_{2}$, insect activity due to elevated temperature and shifts in phenology of both agents and host weeds [136]. However, as both weeds and their bioagents have differential potentials to adapt to new selective pressures, adaptive responses of them to such climatic changes are difficult to predict [137].

\section{Final Thoughts}

There are strong empirical reasons for expecting climate change to alter weed management. In addition to climate change, edaphic factors and crop management practices including use of new classes of herbicides are likely to influence weed biogeography and their degree of damage to agriculture and integrated weed management practices. Furthermore, increasing availability and cultivation of genetically modified crops specific for given herbicides is likely to result in persistence of those herbicides and changes in weed community composition further aggravating the weed management problem. Hence, under the changing climate scenario weed management will be a major concern in the future. Understanding and assessment of the impact of simultaneous change in multiple climate factors and their complex interactions on crops and weeds are therefore necessary to formulate an adaptive weed management approach and build resilience. However, it is likely that with the tremendous effort from the scientific community new weed management strategies (such as new herbicides, herbicide resistant varieties, new bioagents), to build resilience and reduce vulnerability to climate change, will be evolved, but the huge concern remains about the economic, environmental, and health cost of implementing those strategies.

\section{Research Thrust and Policy Recommendations}

(i) Keeping in mind the complexity of climate-soil-crop-weed interaction, extensive research considering different cropping systems under a wide range of climatic and edaphic conditions is required for accurate prediction of the climate change challenge and formulation of long-term weed management strategy. 
(ii) Big data should be developed to better understand the nexus of climate change, weed dynamics, and weed management, and for predictive modeling.

(iii) To reduce the threat posed by aggressive colonizers, emphasis on international and regional cooperation would be very effective to prevent potential cross border spreading of invasive species under the climate change scenario.

(iv) Since agriculture is the major contributor of greenhouse gases like $\mathrm{CH}_{4}$ and $\mathrm{N}_{2} \mathrm{O}$, our attention must be redirected to formulate and expand policies to limit emissions of those gases from the cropland. It seems prudent to aggressively adopt agroforestry opportunities for carbon sequestration benefits, revitalizing conservation agricultural practices like incorporation of allelopathic crop residues and other approaches to holistic weed management.

(v) Strategic policies and strong actions need to be taken to reduce the root causes of $\mathrm{CO}_{2}$ and other greenhouse gas emissions to minimize climate change impact on weeds by various approaches like decreased burning of fossil fuel, reducing deforestation, and substituting alternative energy sources (solar, wind, and hydropower).

Author Contributions: Conceptualization, M.P.A; methodology, M.P.A.; software, M.P.A.; validation, M.P.A., A.K.M.M.I., S.Y. and M.H.R.; formal analysis, M.P.A.; investigation, M.P.A.; resources, M.P.A.; data curation, M.P.A., A.K.M.M.I. and S.Y.; writing-original draft preparation, M.P.A., A.K.M.M.I. and S.Y.; writing-review and editing, A.K.M.M.I., S.Y., M.H.R, S.A., A.S.J. and A.S.; visualization, M.P.A. All authors have read and agreed to the published version of the manuscript.

Funding: This research received no external funding.

Informed Consent Statement: Informed consent was obtained from all subjects involved in the study.

Conflicts of Interest: The authors declare no conflict of interest.

\section{References}

1. UN. United Nations Population Estimates. 2019. Available online: https://www.un.org/development/desa/en/news/ population/world-population-prospects-2019.html (accessed on 13 November 2020).

2. Ziska, L.H. Climate change and the herbicide paradigm: Visiting the future. Agronomy 2020, 10, 1953. [CrossRef]

3. Killman, W. Foreword, in Climate Change and Food Security: A Framework Document; FAO of the United Nations: Rome, Italy, 2008.

4. Ramesh, K.; Matloob, A.; Aslam, F.; Florentine, S.K.; Chauhan, B.S. Weeds in a changing climate: Vulnerabilities, consequences, and implications for future weed management. Front. Plant Sci. 2017, 8, 95. [CrossRef] [PubMed]

5. Amare, T. Review on impact of climate change on weed and their management. J. Agric. Biol. Environ. Stat. 2016, 2, 21-27. [CrossRef]

6. Kang, M.S.; Banga, S.S. Global agriculture and climate change: A perspective. In Combating Climate Change: An Agricultural Perspective; Kang, M.S., Banga, S.S., Eds.; CRC Press: Boca Raton, FL, USA, 2013; pp. 11-25. [CrossRef]

7. Oerke, E.C. Crop losses to pests. J. Agric. Sci. 2006, 144, 31-43. [CrossRef]

8. Chandrasena, N. How will weed management change under climate change? Some perspectives. J. Crop Weed 2009, 5, 95-105.

9. Auld, B.A. The persistence of weeds and their social impact. Int. J. Soc. Econ. 2004, 31, 879-886. [CrossRef]

10. Smith, S.D.; Strain, B.R.; Sharkey, T.D. Effects of $\mathrm{CO}_{2}$ enrichment on four Great Basin grasses. Funct. Ecol. 1987, 1, 139-143. [CrossRef]

11. Webster, C.R.; Jenkins, M.A.; Jose, S. Woody invaders and the challenges they pose to forest ecosystems in the eastern United States. J. For. 2006, 104, 366-374.

12. Pejchar, L.; Mooney, H.A. Invasive species, ecosystem services and human well-being. Trends Ecol. Evol. 2009, 24, 497-504. [CrossRef]

13. IPCC (Intergovernmental Panel on Climate Change). Climate Change 2007: Mitigation of Climate Change Synthesis Report; Cambridge University Press: Cambridge, UK, 2007; p. 15. [CrossRef]

14. Rosenzweig, C.R.; Hillel, D. Climate Change and Global Harvest; Oxford University Press: Oxford, UK, 1998.

15. Upasani, R.R.; Barla, S. Weed dynamics in changing climate. Int. J. Curr. Microbiol. Appl. Sci. 2018, 66, 3435-3450.

16. Field, C.B.; Barros, V.R.; Dokken, D.J.; Mach, K.J.; Mastrandrea, M.D.; Bilir, T.E.; Chatterjee, M.; Ebi, K.L.; Estrada, Y.O.; Genova, R.C.; et al. Climate Change 2014-Impacts, Adaptation and Vulnerability: Regional Aspects; Cambridge University Press: Cambridge, UK, 2014.

17. IPCC (Intergovernmental Panel on Climate Change). Climate Change 2001: The Scientific Basis; Contribution of Working Group I to the Third Assessment Report of the Intergovernmental Panel on Climate, Change; Houghton, J.T., Ding, Y., Griggs, D.J., Noguer, M., van der Linden, P.J., Dai, X., Maskell, K., Johnson, C.A., Eds.; Cambridge University Press: Cambridge, UK, $2001 ;$ p. 881. 
18. IPCC (Intergovernmental Panel on Climate Change). Climate Change 2014: Impacts, Adaptation, and Vulnerability. Part A: Global and Sectoral Aspects; Contribution of Working Group II to the Fifth Assessment Report of the Intergovernmental Panel on Climate Change; Cambridge University Press: Cambridge, UK, 2014. [CrossRef]

19. Stocker, T.F.; Qin, D.; Plattner, G.K.; Tignor, M.; Allen, S.K.; Boschung, J.; Midgley, P.M. Climate Change 2013: THE PHYSICAL SCIENCE Basis; Intergovernmental Panel on Climate Change, Working Group I Contribution to the IPCC Fifth Assessment Report (AR5); Cambridge University Press: New York, NY, USA, 2013; p. 25.

20. Mittler, R.; Finka, A.; Goloubinoff, P. How do plants feel the heat? Trends Biochem. Sci. 2012, 37, 118-125. [CrossRef]

21. Hayman, P.; Sadras, V. Climate change and weed management in Australian farming systems. In Proceedings of the 15th Australian Weeds Conference, Adelaide, Australia, 24-28 Sepetember 2006; Preston, C., Watts, J.H., Crossman, N.D., Eds.; CSIRO: Canberra, Australia, 2006; pp. 22-26.

22. Matzrafi, M.; Seiwert, B.; Reemtsma, T.; Rubin, B.; Peleg, Z. Climate change increases the risk of herbicide-resistant weeds due to enhanced detoxification. Planta 2016, 244, 1217-1227. [CrossRef]

23. Dayan, F.E. Current status and future prospects in herbicide discovery. Plants 2019, 8, 341. [CrossRef]

24. Pautasso, M.; Dehnen-Schmutz, K.; Holdenrieder, O.; Pietravalle, S.; Salama, N.; Jeger, M.J.; Lange, E.; Hehl-Lange, S. Plant health and global change-some implications for landscape management. Biol. Rev. 2010, 85, 729-755. [CrossRef]

25. Andreasen, C.; Skovgaard, I.M. Crop and soil factors of importance for the distribution of plant species on arable fields in Denmark. Agric. Ecosyst. Environ. 2009, 133, 61-67. [CrossRef]

26. Gunton, R.M.; Petit, S.; Gaba, S. Functional traits relating arable weed communities to crop characteristics. J. Veg. Sci. 2011, 22, 541-550. [CrossRef]

27. Fleming, A.; Vanclay, F. Farmer responses to climate change and sustainable agriculture. A review. Agron. Sustain. Dev. 2010, 30, 11-19. [CrossRef]

28. Chauhan, B.S.; Prabhjyot-Kaur Mahajan, G.; Randhawa, R.J.; Singh, H.; Kang, M.S. Global warming and its possible impact on agriculture in India. Adv. Agron. 2014, 123, 65-121. [CrossRef]

29. Holm, L.G.; Doll, J.; Holm, E.; Pancho, J.; Herverger, J. Worlds Weeds: Natural Histories and Distribution; John Wiley \& Sons: New York, NY, USA, 1997; p. 1129.

30. McDonald, A.; Riha, S.; DiTommaso, A.; DeGaetano, A. Climate change and the geography of weed damage: Analysis of U.S. maize systems suggests the potential for significant range transformations. Agric. Ecosys. Environ. 2009, 130, 131-140. [CrossRef]

31. Ziska, L.H.; Dukes, J.S. Weed Biology and Climate Change; Blackwell Publishing Ltd.: Hoboken, NJ, USA, 2011; pp. 68-205. [CrossRef]

32. Boese, S.R.; Wolfe, D.W.; Melkonian, J. Elevated $\mathrm{CO}_{2}$ mitigates chilling-induced water stress and photosynthetic reduction during chilling. Plant Cell Environ. 1997, 20, 625-632. [CrossRef]

33. Parry, M.L. The impact of climate change on European agriculture. In The Bawden Memorial Lectures 1973-1998, Silver Jubilee Edition; Lewis, T., Ed.; British Crop Protection Council: Surrey, UK, 1998; pp. 325-338.

34. Bunce, J.A. Weeds in a changing climate. In Proceedings of the World's Worst Weeds-Proceedings of an International Symposium, Brighton, UK, 12 November 2001; pp. 109-118. Available online: https:/ / www.cabdirect.org/cabdirect/abstract/20023001912 (accessed on 16 April 2021).

35. Singh, M.C.; Dubey, S.C.; Yaduraju, N.T. Climate change and its possible impacts on weeds. Int. J. Environ. Sci. Technol. 2016, 5, 1530-1539.

36. Ziska, L.H.; Tomecek, M.B.; Gealy, D.R. Competitive interactions between cultivated and red rice as a function of recent and projected increases in atmospheric carbon dioxide. Agron. J. 2010, 102, 118-123. [CrossRef]

37. Mahajan, G.; Singh, S.; Chauhan, B.S. Impact of climate change on weeds in the rice-wheat cropping system. Curr. Sci. 2012, 102, 1254-1255.

38. Ziska, L.H.; Goins, E.W. Elevated atmospheric carbon dioxide and weed populations in glyphosate treated soybean. Crop Sci. 2006, 46, 1354-1359. [CrossRef]

39. Luo, Y.; Mooney, H.A. Carbon Dioxide and Environmental Stress; Academic Press: San Diego, CA, USA, 1999.

40. Rodenburg, J.; Meinke, H.; Johnson, D.E. Challenges for weed management in African rice systems in a changing climate. J. Agric. Sci. 2011, 149, 427-435. [CrossRef]

41. Phillips, O.L.; Martinez, R.V.; Arroyo, L.; Baker, T.R.; Killeen, T.; Lewis, S.L.; Malhi, Y.; Mendoza, A.M.; Neill, D.; Vargas, P.N.; et al. Increasing dominance of large lianas in Amazonian forests. Nature 2002, 418, 770-774. [CrossRef]

42. Polley, H.W.; Johnson, H.B.; Tischler, C.R. Woody invasion of grasslands: Evidence that $\mathrm{CO}_{2}$ enrichment indirectly promotes establishment of Prosopis glandulosa. Plant Ecol. 2002, 164, 85-94. [CrossRef]

43. Belote, R.T.; Weltzin, J.F.; Norby, R.J. Response of an understory plant community to elevated $\mathrm{CO}_{2}$ depends on differential responses of dominant invasive species and is mediated by soil water availability. New Phytol. 2003, 161, 827-835. [CrossRef]

44. Mooney, H.A.; Hobbs, R.J. Invasive Species in a Changing World; Island Press: Washington, DC, USA, $2000 ;$ p. 457.

45. Bunce, J.A. Acclimation of photosynthesis to temperature in eight cool and warm climate herbaceous $\mathrm{C}_{3}$ species: Temperature dependence of parameters of a biochemical photosynthesis model. Photosynth. Res. 2000, 63, 59-67. [CrossRef]

46. Ziska, L.H.; Blumenthal, D.M.; Franks, S.J. Understanding the nexus of rising $\mathrm{CO}_{2}$, climate change, and evolution in weed biology. Invasive Plant Sci. Manag. 2019, 12, 79-88. [CrossRef] 
47. Ziska, L.H.; Blumenthal, D.M.; Runion, G.B.; Hunt, E.R., Jr.; Diaz-Soltero, H. Invasive species and climate change: An agronomic perspective. Clim. Change 2011, 105, 13-42. [CrossRef]

48. Liu, Y.; Oduor, A.M.; Zhang, Z.; Manea, A.; Tooth, I.A.; Leishman, M.R.; van Kleunen, M. Do invasive alien plants benefit more from global environmental change than native plants? Glob. Change Biol. 2017, 23, 3363-3370. [CrossRef] [PubMed]

49. Smith, S.D.; Huxman, T.E.; Zitzer, S.F.; Charlet, T.N.; Housman, D.C.; Coleman, J.S.; Fenstermaker, L.K.; Seemann, J.R.; Nowak, R.S. Elevated $\mathrm{CO}_{2}$ increases productivity and invasive species success in an arid ecosystem. Nature 2000, 408, 79-82. [CrossRef] [PubMed]

50. Dukes, J.S.; Chiariello, N.R.; Loarie, S.R.; Field, C.B. Strong response of an invasive plant species (Centaurea solstitialis L.) to global environmental changes. Ecol. Appl. 2011, 21, 1887-1894. [CrossRef]

51. Blumenthal, D.M.; Resco, V.; Morgan, J.A.; Williams, D.G.; LeCain, D.R.; Hardy, E.M.; Pendall, E.; Bladyka, E. Invasive forb benefits from water savings by native plants and C-fertilization under elevated $\mathrm{CO}_{2}$ and warming. New Phytol. 2013, 200, 1156-1165. [CrossRef]

52. Gealy, D.R.; Mitten, D.H.; Rutger, J.N. Gene flow between red rice (Oryza sativa) and herbicide-resistant rice (O. sativa): Implications for weed management. Weed Technol. 2003, 17, 627-645. [CrossRef]

53. Thomson, F.J.; Moles, A.T.; Auld, T.D.; Kingsford, R.T. Seed dispersal distance is more strongly correlated with plant height than with seed mass. J. Ecol. 2011, 99, 1299-1307. [CrossRef]

54. Benech-Arnold, R.L.; Sánchez, R.A.; Forcella, F.; Kruk, B.C.; Ghersa, C.M. Environmental control of dormancy in weed seed banks in soil. Field Crop. Res. 2000, 67, 105-122. [CrossRef]

55. Grossman, J.D.; Rice, K.J. Contemporary evolution of an invasive grass in response to elevated atmospheric CO2 at a Mo-jave Desert FACE site. Ecol. Lett. 2014, 17, 710-716. [CrossRef]

56. Thomas, C.D.; Cameron, A.; Green, R.E.; Bakkenes, B.; Beaumont, L.J.; Collingham, Y.C.; Erasmus, B.F.N.; De Siqueira, M.F.; Grainger, A.; Hannah, L.; et al. Extinction risk from climate change. Nature 2004, 427, 145-148. [CrossRef]

57. Early, R.; Bradley, B.A.; Dukes, J.S.; Lawler, J.J.; Olden, J.D.; Blumenthal, D.M.; Gonzalez, P.G.; Grosholz, E.D.; Ibanez, I.; Miller, L.P.; et al. Global threats from invasive alien species in the twenty-first century and national response capacities. Nat. Commun. 2016, 7, 12485. [CrossRef]

58. Olesen, J.E.; Trnka, M.; Kersebaum, K.C.; Skjelvåg, A.O.; Seguin, B.; Peltonen-Sainio, P.; Rossi, F.; Kozyra, J.; Micale, F. Impacts and adaptation of European crop production systems to climate change. Euro. J. Agron. 2011, 34, 96-112. [CrossRef]

59. Oduor, A.M.O.; Leimu, R.; van Kleunen, M. Invasive plant species are locally adapted just as frequently and at least as strongly as native plant species. J. Ecol. 2016, 104, 957-968. [CrossRef]

60. Das, T.K.; Sharma, A.R.; Pathak, H. Crop-weed balance studies under climate change. In Climate Change Impact, Adaptation and Mitigation in Agriculture: Methodology for Assessment and Application; Pathak, H., Aggarwal, P.K., Singh., S.D., Eds.; Indian Agricultural Research Institute: New Delhi, India, 2012; p. 131.

61. Woodward, F.I.; Cramer, W. Plant functional types and climatic changes: Introduction. J. Veg. Sci. 1996, 7, 306-308. [CrossRef]

62. Peters, K.; Breitsameter, L.; Gerowitt, B. Impact of climate change on weeds in agriculture: A review. Agron. Sustain. Dev. 2014, 34, 707-721. [CrossRef]

63. Patterson, D.T. Implications of global climate change for impact of weeds, insects and plant diseases. Int. Crop Sci. 1993, 1, 273-280. [CrossRef]

64. Patterson, D.T. Effects of environmental stress on weed/crop interactions. Weed Sci. 1995, 43, 483-490. [CrossRef]

65. Sasek, T.W.; Strain, B.R. Implications of atmospheric $\mathrm{CO}_{2}$ enrichment and climatic change for the geographical distribution of two introduced vines in the USA. Clim. Change 1990, 16, 31-51. [CrossRef]

66. Patterson, D.T. Weeds in a changing climate. Weed Sci. 1995, 43, 685-701. [CrossRef]

67. Ziska, L.H. Climate Change Impacts on Weeds, Crop Systems and Global Change Laboratory. Climate Change and Agriculture: Promoting Practical and Profitable Responses. 2010. Available online: http://www.demeter.org.es/pdf/investi_a/Climate_Change_ Impacts_on_Weeds.pdf (accessed on 22 June 2021).

68. Blumenthal, D.; Chimner, R.A.; Welker, J.M.; Morgan, J.A. Increased snow facilitates plant invasion in mixedgrass prairie. New Phytol. 2008, 179, 440-448. [CrossRef]

69. Kriticos, D.J.; Sutherst, R.W.; Brown, J.R.; Adkins, S.W.; Maywald, G.F. Climate change and biotic invasions: A case history of a tropical woody vine. Biol. Invasions 2003, 5, 147-165. [CrossRef]

70. Ziska, L.H.; George, K. Rising carbon dioxide and invasive, noxious plants: Potential threats and consequences. World Res. Rev. 2004, 16, 427-447.

71. Fordham, D.A.; Mellin, C.; Russell, B.D.; Akçakaya, R.H.; Bradshaw, C.J.; Aiello-Lammens, M.E.; Caley, J.M.; Connell, S.D.; Mayfield, S.; Shepherd, S.A.; et al. Population dynamics can be more important than physiological limits for determining range shifts under climate change. Glob. Change Biol. 2013, 19, 3224-3237. [CrossRef] [PubMed]

72. Hulme, P.E.; Barrett, S.C.H. Integrating trait- and niche-based approaches to assess contemporary evolution in alien plant species. J. Ecol. 2013, 101, 68-77. [CrossRef]

73. Mack, R.N.; Simberloff, D.; Lansdale, W.F.; Evans, H. Biotic invasions: Causes, epidemiology, global consequences, and control. Ecol. Appl. 2000, 10, 689-710. [CrossRef]

74. Kathiresan, R.; Gualbert, G. Impact of climate change on the invasive traits of weeds. Weed Biol. Manag. 2016, 16, 59-66. [CrossRef] 
75. Hellmann, J.J.; Byers, J.E.; Bierwagen, B.G.; Dukes, J.S. Five potential consequences of climate change for invasive species. Conserv. Biol. 2008, 22, 534-543. [CrossRef]

76. Irmaileh, B.A. Climate change impact on weeds. In Food Security and Climate Change in Dry Areas, Proceedings of the International Conference, Amman, Jordan, 1-4 February 2010; Solh, M., Saxena, M.C., Eds.; International Center for AgriculturalResearch in the Dry Areas (ICARDA): Aleppo, Syria, 2011; pp. 170-175.

77. Singh, M.K.; Singh, R.K. Alien Invasive Weeds-An Emerging Threat to Agricultural Biodiversity in India. Souvenir-Cum-Abstract, SAARC Workshop on Biodiversity Conservation; Department of Plant Physiology, Institute of Agricultural Sciences, BHU: Varanasi, India, $2010 ;$ p. 91.

78. Singh, R.P.; Singh, R.K.; Singh, M.K. Impact of climate and carbon dioxide change on weeds and their management-a review. Indian J. Weed Sci. 2011, 43, 1-11.

79. Bradley, B.A.; Blumenthal, D.M.; Wilcove, D.S.; Ziska, L.W. Predicting plant invasions in an era of global change. Trends Ecol. Evol. 2010, 25, 310-318. [CrossRef]

80. Acock, B. Effects of Carbon Dioxide on photosynthesis, plant growth, and other processes. In Impact of Carbon Dioxide, Trace Gases, and Climate Change on Global Agriculture; Bruce, A., Chair, K., Rosenberg, N.J., Allen, L.H., Jr., Eds.; ASA Special Publication; American Society of Agronomy, Inc.; Crop Science Society of America, Inc.; Soil Science Society of America, Inc.: Madison, WI, USA, 1990; pp. 45-60. [CrossRef]

81. Naidu, V.S. Invasive potential of $\mathrm{C}_{3}-\mathrm{C}_{4}$ intermediate Parthenium hysterophorus under elevated $\mathrm{CO}_{2}$. Indian J. Agric. Sci. 2013, 83, 176-179.

82. Manisankar, G.; Ramesh, T. Response of weeds under elevated $\mathrm{CO}_{2}$ and temperature: A review. J. Pharmacogn. Phytochem. 2019, SP2, 427-431.

83. Ziska, L.H.; Bunce, J.A. Influence of increasing carbon dioxide concentration on the photosynthetic and growth stimulation of selected $\mathrm{C}_{4}$ crops and weeds. Photosynth. Res. 1997, 54, 199-208. [CrossRef]

84. O'donnell, C.C.; Adkins, S.W. Wild oat and climate change: The effect of $\mathrm{CO}_{2}$ concentration, temperature, and water deficit on the growth and development of wild oat in monoculture. Weed Sci. 2001, 49, 694-702. [CrossRef]

85. Ziska, L.H.; Teasdale, J.R.; Bunce, J.A. Future atmospheric carbon dioxide may increase tolerance to glypho-sate. Weed Sci. 1999, 47, 608-615. [CrossRef]

86. Ziska, L.H. Changes in competitive ability between a $\mathrm{C}_{4}$ crop and a $\mathrm{C}_{3}$ weed with elevated carbon dioxide. Weed Sci. 2001, 49, 622-627. [CrossRef]

87. Ziska, L.H.; Caulfield, F.A. Rising carbon dioxide and pollen production of common ragweed, a known allergy-inducing species: Implications for public health. Aust. J. Plant Physiol. 2000, 27, 893-898. [CrossRef]

88. Wayne, P.S.; Foster, S.; Connolly, J.; Bazzaz, F.A.; Epstein, P.R. Production of allergenic pollen by ragweed (Ambrosia artemissiifolia L.) is increased in $\mathrm{CO}_{2}$-enriched atmospheres. Ann. Allergy Asthma Immunol. 2002, 80, 669-679. [CrossRef]

89. Metz, B.; Davidson, O.; Bosch, P.; Dave, R.; Mayer, L.A. Climate change. In Synthesis Report: Summary for Policymakers; IPCC: Geneva, Switzerland, 2007.

90. Yin, X.; Struik, P.C. Applying modelling experiences from the past to shape crop systems biology: The need to converge crop physiology and functional genomics. New Phytol. 2008, 179, 629-642. [CrossRef]

91. Jagadish, K.S.; Cairns, J.E.; Kumar, A.; Somayanda, I.M.; Craufurd, P.Q. Does susceptibility to heat stress confound screening for drought tolerance in rice. Funct. Plant Biology 2011, 38, 261-269. [CrossRef]

92. Tungate, K.D.; Israel, D.W.; Watson, D.M.; Rufty, T.W. Potential changes in weed competitiveness in an agroecological system with elevated temperatures. Environ. Exp. Bot. 2007, 60, 42-49. [CrossRef]

93. Matsunaka, S. Evolutions of rice weed control practices and research world perspective. In Weed Control in Rice; IRRI: Manila, Philippines, 1983; pp. 5-18.

94. Patterson, D.T. Responses of soybean $\mathrm{CO}_{2}$ enrichment during drought. Weed Sci. 1986, 34, 203-210. [CrossRef]

95. Sun, Y.; Ding, J.; Frye, M.J. Effects of resource availability on tolerance of herbivory in the invasive Alternanthera philoxeroides and the native Alternanthera sessilis. Weed Res. 2010, 50, 527-536. [CrossRef]

96. Malarkodi, N.; Manikandan, N.; Ramaraj, A.P. Impact of climate change on Weeds and Weed management. J. Innov. Agric. 2017, 4, 1-6.

97. Alberto, A.M.P.; Ziska, L.H.; Cervancia, C.R.; Manalo, P.A. The influence of increasing carbon dioxide and tempera-ture on competitive interactions between a C3 crop, rice (Oryza sativa) and a C4 weed (Echinochloa glabrescens). Aust. J. Plant Physiol. 1996, 23, 795-802. [CrossRef]

98. Carter, D.R.; Peterson, K.M. Effects of a $\mathrm{CO}_{2}$-enriched atmosphere on the growth and competitive interaction of a $\mathrm{C}_{3}$ and a $\mathrm{C}_{4}$ grass. Oecologia 1983, 58, 188-193. [CrossRef]

99. Bunce, J.A.; Ziska, L.H. Crop ecosystem responses to climatic change: Crop/weed interactions. In Climate Change and Global Crop Productivity; Reddy, K.R., Hodges, H.F., Eds.; CABI: New York, NY, USA, 2000; pp. 333-348. [CrossRef]

100. Ward, J.K.; Tissue, D.T.; Thomas, R.B.; Strain, B.R. Comparative responses of model C3 and C4 plants to drought in low and elevated $\mathrm{CO}_{2}$. Glob. Change Biol. 1999, 5, 857-867. [CrossRef]

101. Israel, A.A.; Nobel, P.S. Activities of carboxylating enzymes in the CAM species Opuntia Ficus indica grown un-der current and elevated $\mathrm{CO}_{2}$ concentrations. Photosynth. Res. 1994, 40, 223-229. [CrossRef]

102. Poorter, $\mathrm{H}$. Interspecific variation in the growth response of plants to an elevated ambient $\mathrm{CO}_{2}$ concentration. Vegetatio 1993, $104,77-97$. [CrossRef] 
103. Moya, T.B.; Ziska, L.H.; Namuco, O.S.; Olszyk, D. Growth dynamics and genotypic variation in tropical field-grown paddy rice (Oryza sativa L.) in response to increasing carbon dioxide and temperature. Glob. Change Biol. 1998, 4, 645-656. [CrossRef]

104. FAOSTAT. Food and Agriculture Organization of the United Nations. 2020. Available online: http://www.fao.org/faostat/en/\#data/ QC/visualize (accessed on 5 June 2021).

105. Holm, L.G.; Plucknett, D.L.; Pancho, J.V.; Herberger, J.P. The World's Worst Weeds. Distribution and Biology; University Press of Hawaii: Honolulu, HI, USA, 1977.

106. Jinger, D.; Kaur, R.; Kaur, N.; Rajanna, G.A.; Kumari, K.; Dass, A. Weed dynamics under changing climate scenario: A Review. Int. J. Curr. Microbiol. App. Sci. 2017, 6, 2376-2388. [CrossRef]

107. Ziska, L.W. The impact of elevated $\mathrm{CO}_{2}$ on yield loss from a $\mathrm{C}_{3}$ and $\mathrm{C}_{4}$ weed in field-grown soybean. Glob. Change Biol. 2000, 6, 899-905. [CrossRef]

108. Ziska, L.W. Evaluation of yield losss in field sorghum from a $\mathrm{C}_{3}$ and $\mathrm{C}_{4}$ weeds with increasing $\mathrm{CO}_{2}$. Weed Sci. 2003, 51, 914-918. [CrossRef]

109. Carlson, R.W.; Bazzaz, F.A. The effects of elevated $\mathrm{CO}_{2}$ concentrations on growth, photosynthesis, transpiration, and water-use efficiency of plants. In Environmental and Climatic Impact of Coal Utilities; Singh, J.J., Deepak, A., Eds.; Academic Press: New York, NY, USA, 1980.

110. Kimball, B.A.; Idso, S.B. Increasing atmospheric $\mathrm{CO}_{2}$ : Effects on crop yield, water use and climate. Agric. Water Manag. 1983, 7, 55-72. [CrossRef]

111. Drake, B.G.; Gonzàlez-Meler, M.A.; Long, S.P. More efficient plants: A consequence of rising atmospheric $\mathrm{CO}_{2}$ ? Ann. Rev. Plant Physiol. Plant Mol. Biol. 1997, 48, 609-639. [CrossRef]

112. Zhang, W.; Parker, K.M.; Luo, Y.; Wan, S.; Wallace, L.L.; Hu, S. Soil microbial responses to experimental warming and clipping in a tall grass prairie. Glob. Change Biol. 2005, 11, 266-277. [CrossRef]

113. Hall, A.E.; Allen, L.H., Jr. Designing cultivars for the climatic conditions of the next century. In International Crop Science I; Buxton, D.R., Shibles, R., Forsberg, R.A., Blad, B.L., Asay, K.H., Paulsen, G.M., Wilson, R.F., Eds.; Crop Science Society of America, Inc.: Madison, WI, USA, 1993; pp. 291-297. [CrossRef]

114. Bleier, J.S.; Jackson, R.D. Manipulating the quantity, quality and manner of $\mathrm{C}$ addition to reduce soil inorganic $\mathrm{N}$ and increase $\mathrm{C}_{4}: \mathrm{C}_{3}$ grass biomass. Restor. Ecol. 2007, 15, 688-695. [CrossRef]

115. Bailey, S.W. Climate change and decreasing herbicide persistence. Pest Manag. Sci. 2003, 60, 158-162. [CrossRef]

116. Madafiglio, G.P.; Medd, R.W.; Cornish, P.S.; Van de Ven, R. Temperature mediated responses of flumetsulam and metosulam on Raphanus raphanistrum. Weed Res. 2000, 40, 387-395. [CrossRef]

117. Medd, R.W.; Van de Ven, R.; Pickering, D.I.; Nordblom, T. Determination of environment specific dose response relationships for clodinafoppropargyl on Avena spp. Weed Res. 2001, 41, 351-368. [CrossRef]

118. Howden, S.M.; Soussana, J.F.; Tubiello, F.N.; Chhetri, N.; Dunlop, M.; Meinke, H. Adapting agriculture to climate change. Proc. Natl. Acad. Sci. USA 2007, 104, 19691-19696. [CrossRef]

119. Patterson, D.T.; Westbrook, J.K.; Joyce, R.J.V.; Lingren, P.D.; Rogasik, J. Weeds, insects and diseases. Clim. Change 1999, 43, 711-727. [CrossRef]

120. Loladze, I. Hidden shift of the ionome of plants exposed to elevated $\mathrm{CO}_{2}$ depletes minerals at the base of human nutrition. eLife 2014, 3, e02245. [CrossRef]

121. Varanasi, A.; Prasad, P.V.V.; Jugulam, M. Impact of climate change factors on weeds and herbicide efficacy. Adv. Agron. 2015, 135, 107-146. [CrossRef]

122. Patterson, D.T.; Flint, E.P. Implications of increasing carbon dioxide and climate change for plant communities and competition in natural and managed ecosystems. In Impact of Carbon Dioxide, Trace Gases and Climate Change on Global Agriculture; Kimball, B.A., Rosenberg, N.J., Allen, L.H., Jr., Eds.; American Society of Agronomy Special Publication No. 53; American Society of Agronomy: Madison, WI, USA, 1990; pp. 83-110. [CrossRef]

123. Ziska, L.H.; Faulkner, S.S.; Lydon, J. Changes in biomass and root: Shoot ratio of field-grown Canada thistle (Cirsium arvense), a noxious, invasive weed, with elevated $\mathrm{CO}_{2}$ : Implications for control with glyphosate. Weed Sci. 2004, 52, 584-588. [CrossRef]

124. Ziska, L.H.; Teasdale, J.R. Sustained growth and increased tolerance to glyphosate observed in a $\mathrm{C}_{3}$ perennial weed, quackgrass (Elytrigia repens), grown at elevated carbon dioxide. Aust. J. Plant Physiol. 2000, 27, 159-164. [CrossRef]

125. Ziska, L.H.; Reunion, G.B. Future weed, pest and disease problems for plants. In Agroecosystems in a Changing Climate; Newton, P.C.D., Carran, A., Edwards, G.R., Niklaus, P.A., Eds.; CRC: Boston, MA, USA, 2007; pp. $262-279$.

126. Archambault, D.J.; Li, X.; Robinson, D.; O'Donovan, J.T.; Klein, K.K. The effects of elevated $\mathrm{CO}_{2}$ and temperature on herbicide efficacy and weed/crop competition. Rept. Prairie Adapt. Res. Collab. 2001, 29. Available online: https://www.parc.ca/project/ the-effects-of-elevated-co2-and-temperature-on-herbicide-efficacy-and-weed-crop-competition/ (accessed on 24 July 2014).

127. Arıkan, N.; Burçak, A.A.; Türktemel, I.; Akbaş, A. Persistence of herbicide in soil. Turk. J. Occup./Environ. Med. Saf. $2015,1,1$.

128. Nguyen, T.H.; Malone, J.M.; Boutsalis, P.; Shirley, N.; Preston, C. Temperature influences the level of glyphosate resistance in barnyard grass (Echinochloacolona). Pest Manag. Sci. 2015, 72, 1031-1039. [CrossRef]

129. Ziska, L.H. The role of climate change and increasing atmospheric carbon dioxide on weed management: Herbicide efficacy. Agric. Ecosyst. Environ. 2016, 231, 304-309. [CrossRef]

130. Ziska, L.H.; Gealy, D.R.; Tomecek, M.B.; Jackson, A.K.; Black, H.L. Recent and projected increases in atmospheric $\mathrm{CO}_{2} \mathrm{Concen}^{-}$ tration can enhance gene flow between wild and genetically altered rice (Oryza sativa). PLoS ONE 2012, 7, e37522. [CrossRef] 
131. Rogers, H.H.; Runion, G.B.; Krupa, S.V. Plant responses to atmospheric $\mathrm{CO}_{2}$ enrichment, with emphasis on roots and the rhizosphere. Environ. Pollut. 1994, 83, 155-189. [CrossRef]

132. Kriticos, D.J.; Crossman, N.D.; Ota, N.; Scott, J.K. Climate Change and Invasive Plants in South Australia; National Research Flagship Climatic Adaptation: Canberra, Australia, 2010; p. 92.

133. Cardarelli, E.; Musacchio, A.; Montagnani, C.; Bogliani, G.; Citterio, S.; Gentili, R. Ambrosia artemisiifolia control in agricultural areas: Effect of grassland seeding and herbivory by the exotic leaf beetle Ophraella communa. NeoBiota 2018, 38, 1-22. [CrossRef]

134. Ziska, L.H.; Emche, S.D.; Johnson, E.L.; George, K.; Reed, D.R.; Sicher, R.C. Alterations in the production and con-centration of selected alkaloids as a function of rising atmospheric carbon dioxide and air temperature: Implications for ethno-pharmacology. Glob. Change Biol. 2005, 11, 1798-1807. [CrossRef]

135. Gerard, P.J.; Kean, J.M.; Phillips, C.B.; Fowler, S.V.; Withers, T.M.; Walker, G.P.; Charles, J.G. Possible impacts of climate change on biocontrol systems in New Zealand Agri research. Report for MAF Pol Project 0910-11689. 2010. Available online: http:/ / citeseerx.ist.psu.edu/viewdoc/download?doi=10.1.1.224.588\&rep=rep1\&type=pdf (accessed on 14 June 2021).

136. Reeves, J.L. Climate change effects on biological control of invasive plants by insects. CAB Rev. 2017, 12. [CrossRef]

137. Holt, R.D.; Hochberg, M.E. When is biological control evolutionarily stable (or is it)? Ecology 1997, 78, 1673-1683. [CrossRef] 